\title{
DEVELOPING MATERIAL FOR LEARNING VOCABULARY BASED ON PUZZLE GAME FOR THE STUDENTS MAJORING IN ELECTRICAL ENGINEERING OF SMK NEGERI 2 MEDAN
}

\author{
*Nur Fitriani \\ ** Amrin Saragih \\ **Safrida Lubis
}

\begin{abstract}
The objectives of this study were: (1) to develop reading material for tenth grade students of SMK Negeri 2 Medan, (2) to develop students' vocabulary by playing puzzles as the task. This study was conducted by Research and Development (R\&D). The research procedures were adapted from Borg and Gall. This research were designed through six phases; 1) gathering data and information, 2) analyzing the data, 3) designing materials, 4) validating materials, 5) revising, and 6) final product. The data of this research were taken from existing materials, syllabus, teacher's interview and students' questioners. The result of this study showed that the students' existing material were not relevant to electrical engineering program. The vocabulary that students' get from the existing materials was less. The designing material was validated by English teacher and English lecturer. The product of this study is a set of reading material entitled "electricity holic" for students in SMK Negeri 2 Medan. The reading materials consist of three genres; descriptive, narrative and recount.
\end{abstract}

Key words: Reading material, Research and Development (R\&D), SMK Negeri 2 Medan, Puzzle, Vocabulary.

\footnotetext{
*Graduate Status

**Lecturer Status
} 


\title{
INTRODUCTION
}

\author{
Background of the Study
}

Vocabulary is a vital part of language that students need to master in order to communicate effectively. Without grammar people will a little bit hard to deliver the communication, without vocabulary there is nothing can be communicate (Wilkins, 1972). It means that vocabulary is the most important thing in learning English language. The ability to grasp the meaning of new words is a necessary skill to strengthen retention of vocabulary. In studying English, students in vocational high school (VHS) thought it was difficult to grasp the new word, even in common vocabulary.

Nowadays, Electrical Engineering has been one of the major in vocational high school. The students' need in electrical engineering must be different in general school. They should master their own major. Analyse the syllabus in vocational high school in SMK Negeri 2 Medan, There is no specific connection between the major and the material they have been taught in English. So, students in this major lack of specific vocabulary things that they use every day.

Students in electrical majoring need vocabulary which is related to their own program. They can reach the vocabulary from their textbook or from their teacher. Besides of the lack of vocabulary in their textbook which is not related to their program, and how the teacher delivered the lesson, the other problem of this situation caused of uninterested learning process.

To create an atmosphere of interactive learning in the classroom, the teacher as the facilitator should have to build an impressive classroom management. Teacher should have the solution to make the students become interest and not difficult to remember and explore ideas in studying English. Teacher is responsible to create a constructive classroom management. In this case, teacher should have a way to help students to learn vocabulary in context.

There is a way to make the students become interested in studying English. Game is an alternative way to make learning joyful. Games are highly motivating because they are amusing and interesting. They can be used to give practice in all language skills and be used to practice many types of communication. From the state above, the use of games in teaching English has increased the student's attention and motivation and it is very useful to use games. 
Puzzle is games that can test knowledge, skill, and intelligence. Puzzle game is an interesting and fun way to apply in the class. Puzzles are often perceived as being a recreational activity, therefore making students more enjoyable than traditional teaching techniques. That is how game can build an enjoyable learning process. Another positive outcome of using games in the classroom is that the students will have directed experience.

\section{Research Method}

The research of needs analysis for students was conducted on February, 2017 at SMK Negeri 2 Medan. The subject of this research was 28 students of Grade X of Elictrical Engineering. The procedure of the research was based on Borg \& Gall's (2003) through six steps: 1.Gathering Information and data, 2.Analyzing Data, 3.Designing Materials, 4.Validating by Experts, 5.Revising Materials, and 6.Final Product.

The collecting data techniques in this study were questioner. There are two types of questionnaires were used as the instrument. The first was as the need analysis questionnaire which was made to obtain the data about the students' target and learning needs and the second was as the expert judgment questionnaires which made to obtain the data about the appropriateness of the data materials developed. The quantitative of data from the needs analysis were calculated manually by the researcher using frequency and percentage. Whereas, the qualitative of data from the expert judgment were calculated by using central tendency measure especially the mean. Then, the means (M) of data which had been calculated were converted into a descriptive analysis. The parameter of classifying of the means, the researcher used quantitative data conversion proposed by Suharto (2006).

\section{Research Finding and Discussion}

\section{Research Findings}

\section{Gathering Data and Information}

The information was gathered through by syllabus, existing material, teacher's interview, and student's questioner. The results were found that 1) the reading materials in English text book were less appropriate for students' need in electrical major and 2) there should be developing materials which fulfilled students' needs. The questionnaires were 
distributed to 28 students of class X-5LP majoring electrical engineering of SMK Negeri 2 Medan.

2. Need Analysis

This stage was aimed to get the information about the target needs and learning needs to learning English. There were $85.1 \%$ said that the use text related to their major in teaching and learning reading skill is very important. There were $77.8 \%$ said that providing the vocabulary in arrange the materials are very helpful to read and understanding the text. There were 88.9\% said that applying game as the technique in English learning process will make them more interesting. There were $44.4 \%$ of respondents said that most of them wanted Type activity that in learning vocabulary is completing the sentence with using puzzle games. Then $70 \%$ of respondents said when they learn reading, it is better if the teacher gives examples or explanation first about how to do the tasks then ask students to do it.

\section{Designing Material}

Designing English reading material were done by considering the students' needs. At this stage, the reading material was developed based on the data resulted from the questionnaires in needs analysis, existing material, curriculum 2013 and syllabus.

In designing the English reading materials, the researcher divided the English reading materials related to the students of Electrical Engineering study program into three units, those are descriptive, narrative and recount. The whole units consist of 5 tasks. Each unit consists of several tasks including puzzle games that develop students' vocabulary. The three units were developed by selecting English reading materials related to students of Electrical Engineering study program in the internet and book. In this development, some original ideas of the researcher were included.

\section{Validating by expert}

The developed English reading materials were validated by the experts. Questionnaires sheet was used to know the experts' result about developing new English reading materials as the learning material in teaching reading especially for descriptive text. The questionnaire was made up based on rating scale. The scale are (5) Very Good, (4) Good, (3) Fair, (2) Poor, (1) Very Poor. The expert's questionnaire filled by Indra Hartoyo, S.Pd., M.Hum as the English lecturer in Sate University of Medan. And Rifka D. 
Siregar, S.Pd as the English teacher in SMK Negeri 2 Medan. There were 4 aspects to identify the appropriateness of developing English reading materials. There are the appropriateness of content, appropriateness of the language, appropriateness of the presentation, and appropriateness of the layout. The data of experts' validation can be seen in table below.

Table 1 The data of expert's validation to content aspect

\begin{tabular}{|l|c|c|c|}
\hline \multirow{2}{*}{ Items Assessed } & \multicolumn{2}{|c|}{ Experts } & \multirow{2}{*}{ Criteria } \\
\cline { 2 - 3 } & I & II & \\
\hline $\begin{array}{l}\text { Content } \\
\text { Appropriateness }\end{array}$ & 4.5 & 4.5 & $4.5 /$ Very Good \\
\hline $\begin{array}{l}\text { Language } \\
\text { Appropriateness }\end{array}$ & 4.7 & 4.5 & $4.6 /$ Very Good \\
\hline $\begin{array}{l}\text { Presentation } \\
\text { Appropriateness }\end{array}$ & 4.6 & 4.5 & $4.55 /$ Very Good \\
\hline $\begin{array}{l}\text { Graphic } \\
\text { Appropriateness }\end{array}$ & 5 & 4.8 & $4.9 /$ Very Good \\
\hline
\end{tabular}

Based on table above, the developed materials can be categorized as very good and considered appropriate for Grade X students of Light Vehicle Engineering Program especially for their reading skill.

5. Revising

The developed English reading materials had been evaluated by the experts. There were some revisions as suggested by the experts; English teacher's suggestion was to give more explanation about the generic structure of the text and English lecturer suggestion was to improve the language.

6. Final product

English teacher as the first validation categorized that the developed English reading material as relevant and appropriate. English lecturer as the second validation was categorized that English reading material was relevant and appropriate. Finally, the final product or developed material 
was valid to use as learning material for students majoring in electrical engineering in SMK Negeri 2 Medan.

\section{Discussion}

The aim of this research was to develop appropriate reading material and increase students' vocabulary of the students of tenth grade of SMK Negeri 2 Medan. The population of the sample were 27 students of tenth grade. In developing reading material, there were several steps to develop; those were gathering information, need analysis, designing material, getting the expert judgment, revising and final product.

The researcher developed English reading materials in this research because there is no correlation between the reading text and students major. The reading materials should bring it into line with students' need. The questioners and interview were given to gather the information about it.

After finding the students' needs, the researcher designed the materials, the product was validated by two experts; English teacher and English lecturer. The experts gave some recommendation on developing the materials. After giving the recommendation, the expert gave the score in validation sheet. Based on the score from two experts, the average score was 4,71 and 4,58 which categorized as very good or relevant. The revision that was given by both of the experts for developing materials would become a final product.

\section{Conclusion and Suggestion}

\section{The Conclusion}

Based on the development result of this researcher in the fifth chapter, it can be conclude that the existing materials are too generals for the students of Electrical Engineering. Need analysis from the questionnaire and interview showed that the students of SMK Negeri 2 Medan particularly in electrical engineering major needed an appropriate English reading material which could support their expertise program and motivate them in learning activity. The students enjoyed if playing game make them more interesting in doing the task. The English reading materials were developed in order to find the appropriate materials based on students' needs and help the students to increase their vocabulary and knowledge about electricity. 


\section{The Suggestion}

There were some suggestions given for the consideration the future. For the teacher, should considering the appropriate material for students' needs in teaching and learning process should be done first. The learning process can be success if the reading materials were useful for their expertise. Teacher should find the way to attract students' interest in the classroom. The related topic to the students, especially for electrical engineering students should be developed by the teacher. For students, if the existing reading material did not appropriate with electrical engineering program, the students can find it from the internet and other sources. The last, for other developer, to conducting the students' need is the most important thing in developing materials. The product of the research should fulfill students' needs and interest.

\section{REFERENCES}

Bahrick (1984) The Effectiveness Of Using Puzzle In Developing Palestinian Tenth Graders' Vocabulary Achievement And Retention. Humanities and Social Sciences. Vol. 1, No. 1, 2013, pp. 46-57.

Borg, W.R and Gall, M.D. 2003. Educational Research An Introduction. New York: Longman.

Govindasamy, K (2010). Electrical Engineering (Electrical Machines and Appliances). College Road, Chennai.

Hutchinson, T \& Waters, A. 1986. English for Specific Purpose: A Learning-centred approach. Cambride: Cambride university Press.

Nunan, D. (2003). Practical English Language Teaching. Singapore: McGraw-Hill Companies, Inc.

Pardiyono. (2007). Pasti Bisa: Teaching Genre-Based Writing. Yogyakarta: Andi Publisher.

Simpson, Adam. 2015. Using Games in the Language Classroom. Smashwords.

Thornbury, S.2002. How to Teach Vocabulary. Person education limited: England. 
Tomlinson, Brian (2011). Material development in Language Teaching $\left(2^{\text {nd }}\right.$ Ed.). Cambridge: Cambridge University Press. 